\title{
Carabid beetle occurrence at the edges of oak and beech forests in NW Spain
}

\author{
Angela TABOADA ${ }^{1}$, D. Johan KOTZE² and José M. SALGADO ${ }^{1}$ \\ 'Departamento de Biología Animal, Universidad de León, E-24071 León, Spain; e-mail: dbaatp@unileon.es \\ ${ }^{2}$ Department of Biological and Environmental Sciences, PO Box 65, FIN-00014 University of Helsinki, Finland
}

Key words. Beech forest, carabid beetles, edge effects, forest edge, oak forest

\begin{abstract}
We examined the occurrence of carabid beetles (Coleoptera, Carabidae) at the edges of oak (Quercus pyrenaica) and beech (Fagus sylvatica) forests in León, NW Spain. Pitfall traps were used to collect beetles from April to October 2002, and leaf litter cover and depth were measured. Traps were placed at three distances $(0,50$ and $100 \mathrm{~m})$ from the edges of eight forest patches. A total of 5436 carabids belonging to 43 species were collected. We found no statistically significant edge effect at the carabid assemblage level, i.e. the number of species and individuals was not higher at the edge compared to the forest interior. However, individual species were affected by distance from the edge. Five of the 14 species analysed responded predictably to the edge, three of them statistically significantly so. Four species did not respond in the predicted direction, two of them statistically significantly so. We found a considerable difference between forest types in terms of carabid assemblage composition and response to the edge. Oak forests were species richer and beech forests had a higher number of individuals. These differences were probably due to smallscale habitat heterogeneity in the oak forest patches, caused by man, and the homogeneous structure of beech forests. Leaf litter appeared to be one possible factor influencing the distribution of some species from the interior to the edge of forests.
\end{abstract}

\section{INTRODUCTION}

A consequence of fragmentation is an increase in edge habitat per unit area compared to continuous habitats (Haila, 1999; Matlack \& Litvaitis, 1999). This edge habitat can have either positive or negative effects on organisms (Angelstam, 1992; Matlack \& Litvaitis, 1999), and represents a zone characterised by extreme abiotic conditions that affect species and ecological processes (Debinski \& Holt, 2000). The edge effect is complex and is defined as a group of phenomena, i.e. changes in environmental and biological conditions, which result from the interaction between two adjacent ecosystems separated by an abrupt transition zone (Murcia, 1995).

Abiotic changes that occur at the edge of forests include higher light intensity, temperature and wind, which may cause edges to be drier than forest interiors (Murcia, 1995; Didham, 1997a; Kapos et al., 1997; Laurance, 1997). Forest edges are also characterised by increased tree mortality, invasion of generalist plants and lower dicotyledonous seedling densities (Murcia, 1995; Kapos et al., 1997; Turton \& Freiburger, 1997). These features vary with edge age and matrix type (Kolasa \& Zalewski, 1995; Murcia, 1995; Donovan et al., 1997; Kapos et al., 1997).

The variability in the abiotic environment and vegetation characteristics at edges affect the distribution and composition of animals (Murcia, 1995; Didham, 1997b; Jokimäki et al., 1998) at different temporal and spatial scales (see Kolasa \& Zalewski, 1995; Murcia, 1995; Risser, 1995). Examples of taxa sensitive to edge conditions include birds (Paton, 1994; McCollin, 1998), small mammals (Stevens \& Husband, 1998) and amphibians (Demaynadier \& Hunter, 1998).
Insects too are influenced by edge effects. Didham (1997b) argued that changes in abiotic factors that occur at edges are mainly responsible for the responses of invertebrates to fragmentation, especially in habitat specialist species. Carabid beetles have been used to study the effects of fragmentation (Niemelä et al., 1993; De Vries, 1996; Luff, 1996; Spence et al., 1996; Davies \& Margules, 1998; Tischendorf, 1998; Abildsnes \& Tømmerås, 2000) and are considered to be sensitive indicators of fragmentation (Niemelä, 2001; Rainio \& Niemelä, 2003). However, the effects of habitat edges on carabids are ambiguous. Magura (2002) found a significantly higher species richness at the edge than in the interior of a forest in northern Hungary, while Kotze \& Samways (2001) found no significant changes in carabid species richness across edges in Afromontane forests in South Africa. Heliölä et al. (2001) showed that the carabid assemblage in the interior was similar to that at the edge of boreal forests in central Finland. This ambiguity may be because the response of individual species depends on their habitat requirements (Spence et al., 1996; Davies \& Margules, 1998), and the different forest types studied.

The aim of this study is to test the effects of beech and oak forest edges on carabid beetle assemblages in NW Spain. We are unable to predict the pattern of overall carabid abundance at forest edges compared to interiors, as several authors record increases (Magura \& Tóthmérész, 1998), decreases (Kotze \& Samways, 2001; Magura et al., 2001a) or no change (Heliölä et al., 2001). We expect little change in the number of species, i.e. species richness, from the edge to the forest interior (Heliölä et al., 2001; Kotze \& Samways, 2001), as open habitat species may be abundant at the edges and forest specialists in the interior. Should we find a higher carabid species richness at the forest edge we shall explore whether this is 
due to the presence of edge-associated species (Spence et al., 1996; Matlack \& Litvaitis, 1999; Heliölä et al., 2001; Magura et al., 2001b; Mólnar et al., 2001).

In terms of individual species, habitat generalists are expected to be little influenced by the edge, while forest specialist species are expected to be negatively influenced. Open habitat species are expected to be more abundantly collected at forest edges than interiors. We also expect a greater effect at the edges of beech than oak forests, since oak forests are more heterogeneous with open and dry areas in the forest interior. Beech forest interiors are more homogeneous in terms of environmental conditions such as temperature and darkness. Consequently, the transition between forest interior and edge is expected to be more abrupt in beech than oak forests.

\section{MATERIAL AND METHODS}

\section{Study area}

Beech (Fagus sylvatica) and oak (Quercus pyrenaica) forests are widely distributed in the mountainous region of León, NW Spain. Historically, this area was strongly influenced by man (Luis-Calabuig et al., 2000) and is characterised by forest habitat surrounded by a mosaic of agricultural and pastoral land. Consequently, the landscape consists of sharp boundaries between forest and the surrounding habitat. Little is known, however, about the distribution patterns and responses of carabid beetles across these sharp boundaries in NW Spain. In fact, very few studies exist on the relationships between carabid beetles and their habitat requirements (vegetation and soil characteristics) in Spain (e.g. Salgado et al., 1998; Gutiérrez et al., 2004).

The study was carried out in eight forest patches in the province of León, NW Spain $\left(42^{\circ} 37^{\prime}-43^{\circ} 6^{\prime} \mathrm{N}, 4^{\circ} 55^{\prime}-5^{\circ} 12^{\prime} \mathrm{W}\right)$. We selected four oak (Quercus pyrenaica) and four beech (Fagus sylvatica) patches, each separated by more than $2 \mathrm{~km}$. Oak forests are included in the Festuco heterophyllae-Querceto pyrenaicae sigmetum in the Mediterranean Region (Penas et al., 1995), and are located at altitudes between 884 and $922 \mathrm{~m}$. Forest interiors are sunny, dry, with nutrient poor and stony soil, and with open areas that create high habitat heterogeneity. Forest edges are dominated by shrubs of the association Genistello tridentatae-Ericetum aragonensis cistetosum laurifolii in wet areas and the Cytiso scoparii-Genistetum polygaliphyllae lavanduletosum pedunculatae association in dry areas. There are also small oak saplings and dense herbaceous vegetation with Festuca and Trifolium species at the edges.

Beech forests belong to the Blechno spicanti-Fageto sylvaticae sigmetum in the Eurosiberian Region (Penas et al., 1995), at altitudes between 1250 and $1433 \mathrm{~m}$. Forest interiors are wet, shaded and with a deep leaf litter layer. Forest edges are characterised by meadow vegetation (Merendero pyrenaicae-Cynosuretum cristati) with few shrubs (Cytisus and Genista species).

\section{Sampling method}

We used glass pitfall traps (depth $80 \mathrm{~mm}$, diameter $70 \mathrm{~mm}$ ) to sample the beetles. Traps were partly filled with $30 \%$ alcohol and detergent. We placed two $30 \mathrm{~cm}$ long plastic guides $(-\mathrm{O}-)$ per trap to increase carabid catches (Winder et al., 2001), and covered the traps with flat stones to prevent the traps from filling up with rain water and leaves. Beetles were collected over their whole activity period from April to October 2002, by keeping the traps open for 12-15 days each month. Five traps (1-2 $\mathrm{m}$ apart) were placed in a line at three distances in each forest patch (at the edge, at $50 \mathrm{~m}$ and at $100 \mathrm{~m}$ into the forest patches). This resulted in a total number of 120 pitfall traps. Beetles were identified using standard keys (Jeannel, 1941-1942; Lindroth, 1974; Trautner \& Geigenmüller, 1987) and the nomenclature follows Serrano (2003).

We estimated the coverage and depth of leaf litter at each distance from the edge $(0,50$ and $100 \mathrm{~m})$ within a $2 \mathrm{~m}$ radius of each of the groups of five traps.

\section{Statistical analysis}

We pooled the carabid catches at each sampling point, i.e. the catches in the five traps in a line at each distance from the edge $(0,50$ and $100 \mathrm{~m})$, and for the whole trapping period. This resulted in four replicate samples per distance from the edge per forest type. Carabid species were classified as forest specialists, generalists or open habitat species, according to the literature (see Table 1).

Generalised Linear Models were used for the statistical analyses. Species collected from at least 6 of the 12 samples in each forest type were analysed individually, while the rest of the species were pooled according to their classification as forest, open habitat or generalist species (Table 1). The response variables in the models were the number of individuals (overall and for individual species) and number of species, and the predictor variables leaf litter cover, leaf litter depth and distance from the edge (see Quinn \& Keough, 2002). Leaf litter variables were included in the models but we did not make specific predictions regarding the responses of the beetles to litter. The effects of litter were explored if found statistically significant in the models, repeating the analyses for those species without leaf litter cover and depth to evaluate the effects of these characteristics on the pattern relative to the distance from the forest edge.

We assumed a clumped spatial distribution for carabid beetles (Niemelä et al., 1996) and consequently defined the response variables (i.e. abundance) in the analyses as following a negative binomial error distribution (White \& Bennetts, 1996). Theta $(\theta)$, the dispersion parameter was, however, high for certain species, which were subsequently re-analysed by defining abundance as following a Poisson error distribution. Overall species richness was modelled following a Poisson error distribution.

In addition, we estimated distinctness in species composition at the three distances from the forest edge $(0,50$ and $100 \mathrm{~m})$ in each forest type, using the complementarity index in Colwell \& Coddington (1995):

$$
\mathrm{C}_{\mathrm{jk}}=\mathrm{U}_{\mathrm{jk}} / \mathrm{S}_{\mathrm{jk}} \text {, }
$$

where $U_{j k}$ is the number of species unique to each distance within the forest type, defined as $U_{j k}=S_{j}+S_{k}-2 V_{j k}$, and $S_{j k}$ is the total richness for two distances combined, defined as $S_{j k}=S_{j}$ $+\mathrm{S}_{\mathrm{k}}-\mathrm{V}_{\mathrm{jk}} . \mathrm{S}_{\mathrm{j}}$ and $\mathrm{S}_{\mathrm{k}}$ represent the local richness at each distance, and $V_{j k}$ is the number of species that occur at both distances. Complementarity values vary from 0 to 1 , indicating high to low number of species in common, respectively.

\section{RESULTS}

A total of 5436 carabids belonging to 43 species were collected (Table 1). The most abundant species were the 2803 individuals of Nebria asturiensis $(51.6 \%$ of the total catch), and 1321 individuals of Pterostichus cantaber $(24.3 \%)$. Both species were collected from all 12 beech forests sites, but not from oak forests. Cryobius cantabricus (241 individuals) and Carabus lineatus (221 individuals) were also abundantly captured in beech forests. In oak forests, Steropus globosus was the most abundant 
TABLE 1. Carabid beetles collected at three distances from the edges $(0,50$ and $100 \mathrm{~m})$ of beech and oak forest patches. Size $=$ carabid beetle body size range in $\mathrm{mm}$. Wings $=$ wing morphology $(\mathrm{b}=$ brachypterous, micropterous or flightless, i.e. unable to fly; $\mathrm{m}=\mathrm{macropterous;} \mathrm{D}=\mathrm{dimorphic})$. Habitat $=$ habitat association of the species $(\mathrm{F}=$ forest, $\mathrm{G}=$ generalist and $\mathrm{O}=$ open habitat species). Literature used: De la Fuente (1927), Jeannel (1941-1942), Lindroth (1974), Vázquez (1990), Andújar \& Serrano (2001) and Ortuño \& Marcos (2003).

\begin{tabular}{|c|c|c|c|c|c|c|c|c|c|c|}
\hline & \multirow{2}{*}{ Size } & \multirow{2}{*}{ Wings } & \multirow{2}{*}{ Habitat } & \multicolumn{3}{|c|}{ Beech Forest } & \multicolumn{4}{|c|}{ Oak Forest } \\
\hline & & & & $0 \mathrm{~m}$ & $50 \mathrm{~m}$ & $100 \mathrm{~m}$ & $0 \mathrm{~m}$ & $50 \mathrm{~m}$ & $100 \mathrm{~m}$ & Total \\
\hline Agonum (Agonum) viridicupreum viridicupreum (Goeze, 1777) & $8.0-10.0$ & $\mathrm{~m}$ & $\mathrm{O}$ & & & & 1 & & & 1 \\
\hline Amara (Amara) aenea (De Geer, 1774) & $6.0-8.0$ & $\mathrm{~m}$ & $\mathrm{O}$ & 1 & & & & & & 1 \\
\hline Amara (Percosia) equestris equestris (Duftschmid, 1812) & $8.0-13.0$ & $\mathrm{~m}$ & G & & 1 & & 2 & & & 3 \\
\hline Amara (Leironotus) glabrata Dejean, 1828 & $6.0-7.0$ & $\mathrm{~b}$ & $\mathrm{O}$ & & & & 1 & & & 1 \\
\hline Amara (Amara) ovata (F., 1792) & $8.0-10.0$ & $\mathrm{~m}$ & $\mathrm{O}$ & & & & & 1 & & 1 \\
\hline Anchomenidius astur (Sharp, 1873) & $5.0-5.5$ & $\mathrm{~b}$ & $\mathrm{~F}$ & & 1 & & & & & 1 \\
\hline Bembidion (Nepha) callosum subconnexum De Monte, 1953 & $3.5-4.0$ & $\mathrm{~m}$ & G & & & & 1 & & & 1 \\
\hline Calathus (Calathus) fuscipes graecus Dejean, 1831 & $10.0-15.0$ & $\mathrm{~b}$ & G & 81 & 5 & 2 & 12 & 3 & 4 & 107 \\
\hline Calathus (Neocalathus) granatensis Vuillefroy, 1866 & $9.5-12.0$ & $\mathrm{D}$ & G & & & & & 9 & 30 & 39 \\
\hline Calathus (Neocalathus) melanocephalus melanocephalus (L., 1758) & $6.0-8.0$ & $\mathrm{D}$ & $\mathrm{O}$ & & & & & 1 & & 1 \\
\hline Calathus (Neocalathus) rotundicollis Dejean, 1828 & $9.0-12.0$ & $\mathrm{D}$ & $\mathrm{F}$ & 14 & 19 & 19 & 1 & 44 & 30 & 127 \\
\hline Carabus (Oreocarabus) amplipennis getschmanni Lapouge, 1924 & $18.0-22.0$ & $\mathrm{~b}$ & $\mathrm{~F}$ & 53 & 12 & 3 & 1 & 4 & 3 & 76 \\
\hline Carabus (Chrysocarabus) lineatus lineatus Dejean, 1826 & $24.0-32.0$ & $\mathrm{~b}$ & $\mathrm{~F}$ & 59 & 61 & 101 & & & & 221 \\
\hline Carabus (Mesocarabus) lusitanicus complanatus Dejean, 1826 & $20.0-26.0$ & $\mathrm{~b}$ & $\mathrm{~F}$ & & & & 1 & & 8 & 9 \\
\hline Carabus (Mesocarabus) macrocephalus macrocephalus Dejean, 1826 & $25.0-30.0$ & $\mathrm{~b}$ & $\mathrm{~F}$ & 19 & 15 & 17 & & & & 51 \\
\hline Carabus (Archicarabus) nemoralis prasinotinctus Heyden, 1880 & $20.0-26.0$ & $\mathrm{~b}$ & G & 2 & 1 & & 2 & 13 & 11 & 29 \\
\hline Carabus (Megodontus) violaceus aurichalceus Kraatz, 1879 & $20.0-34.0$ & $\mathrm{~b}$ & G & 1 & & & & & & 1 \\
\hline Cryobius cantabricus cantabricus (Schaufuss, 1862) & $7.5-8.0$ & $\mathrm{~b}$ & $\mathrm{~F}$ & 55 & 71 & 115 & & & & 241 \\
\hline Cychrus spinicollis spinicollis Dufour, 1857 & $13.0-18.0$ & $\mathrm{~b}$ & $\mathrm{~F}$ & 3 & 4 & 11 & & & & 18 \\
\hline Cymindis (Cymindis) alternans alternans Rambur, 1837 & $7.5-9.0$ & $\mathrm{~b}$ & $\mathrm{O}$ & & & & 1 & 1 & & 2 \\
\hline Dinodes (Dinodes) dives kricheldorffi (Wagner, 1932) & $11.0-12.0$ & $\mathrm{~b}$ & $\mathrm{O}$ & & & & & & 1 & 1 \\
\hline Harpalus (Harpalus) ebeninus Heyden, 1870 & $10.0-12.0$ & $\mathrm{~b}$ & $\mathrm{O}$ & & & & & & 1 & 1 \\
\hline Harpalus (Harpalus) rufipalpis rufipalpis Sturm, 1818 & $7.0-9.0$ & $\mathrm{~m}$ & $\mathrm{O}$ & & & & & & 1 & 1 \\
\hline Harpalus (Harpalus) serripes serripes (Quensel, 1806) & $10.0-12.0$ & $\mathrm{~m}$ & $\mathrm{O}$ & & & & 1 & & & 1 \\
\hline Laemostenus (Pristonychus) terricola terricola (Herbst, 1783) & $10.0-18.0$ & $\mathrm{~b}$ & G & 2 & 7 & 13 & & & & 22 \\
\hline Lebia (Lebia) marginata (Geoffroy, 1785) & $4.0-4.5$ & $\mathrm{~m}$ & $\mathrm{O}$ & & & & & 2 & & 2 \\
\hline Leistus (Leistus) barnevillei Chaudoir, 1867 & $7.0-9.0$ & $\mathrm{~b}$ & $\mathrm{~F}$ & 3 & 10 & & & & & 13 \\
\hline Leistus (Leistus) nitidus (Duftschmid, 1812) & $7.5-9.0$ & $\mathrm{~b}$ & $\mathrm{~F}$ & 5 & 29 & 19 & & & & 53 \\
\hline Licinus (Licinus) aequatus angustus Chevrolat, 1840 & $11.0-14.0$ & $\mathrm{~b}$ & G & & 1 & 1 & & & & 2 \\
\hline Microlestes negrita negrita Wollaston, 1854 & $2.2-2.8$ & $\mathrm{D}$ & G & & & & 1 & & & 1 \\
\hline Nebria (Nebria) asturiensis Bruneau de Miré, 1964 & $10.5-13.5$ & $\mathrm{~b}$ & $\mathrm{~F}$ & 558 & 960 & 1285 & & & & 2803 \\
\hline Notiophilus biguttatus (F., 1779) & $5.0-5.5$ & $\mathrm{D}$ & G & 25 & 15 & 28 & & 3 & & 71 \\
\hline Ophonus (Metophonus) puncticeps Stephens, 1828 & $6.0-9.0$ & $\mathrm{~m}$ & $\mathrm{O}$ & & & & 1 & & & 1 \\
\hline Orthomus (Orthomus) hispanicus (Dejean, 1828) & $9.0-11.0$ & $\mathrm{~b}$ & $\mathrm{O}$ & & & & 2 & & & 2 \\
\hline Panagaeus cruxmajor (L., 1758) & $7.5-8.0$ & $\mathrm{~m}$ & G & & & & & 1 & & 1 \\
\hline Poecilus (Macropoecilus) kugelanni (Panzer, 1797) & $12.0-14.0$ & $\mathrm{~m}$ & $\mathrm{O}$ & 1 & & & & 3 & 7 & 11 \\
\hline Poecilus (Poecilus) versicolor (Sturm, 1824) & $9.0-11.0$ & $\mathrm{~m}$ & $\mathrm{O}$ & & & & 11 & & & 11 \\
\hline Pterostichus (Oreophilus) cantaber (Chaudoir, 1868) & $13.0-16.0$ & $\mathrm{~b}$ & $\mathrm{~F}$ & 217 & 454 & 650 & & & & 1321 \\
\hline Steropus (Steropidius) gallega (Fairmare, 1859) & $13.0-16.0$ & $\mathrm{~b}$ & G & 21 & 2 & 2 & & & & 25 \\
\hline Steropus (Sterocorax) globosus ebenus (Quensel, 1806) & $13.5-20.0$ & $\mathrm{~b}$ & G & & & & 61 & 3 & 44 & 108 \\
\hline Trechus (Trechus) obtusus asturicus Jeannel, 1921 & $3.2-4.0$ & $\mathrm{D}$ & $\mathrm{O}$ & & & & 3 & 29 & 6 & 38 \\
\hline Trechus (Trechus) quadristriatus (Schrank, 1781) & $3.2-4.0$ & $\mathrm{~m}$ & $\mathrm{O}$ & & & 1 & 1 & 11 & 2 & 15 \\
\hline Zabrus (Iberozabrus) silphoides asturiensis Heyden, 1880 & $11.0-16.5$ & $\mathrm{~b}$ & $\mathrm{O}$ & & & & 1 & & & 1 \\
\hline Number of individuals & & & & 1120 & 1668 & 2267 & 105 & 128 & 148 & 5436 \\
\hline Number of species & & & & 18 & 18 & 15 & 19 & 15 & 13 & 43 \\
\hline
\end{tabular}



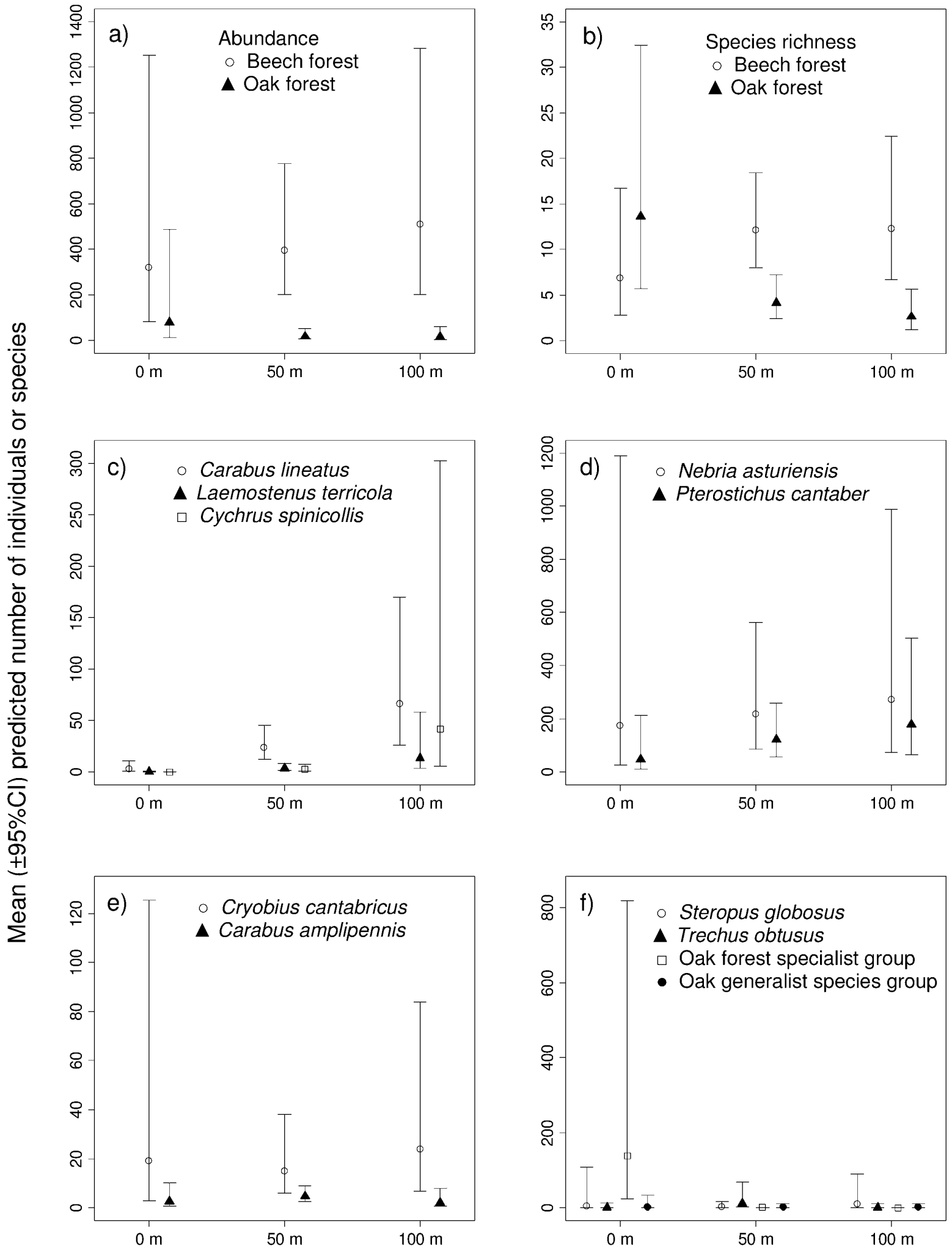

Distance from the edge

Fig. 1. Carabid beetle responses to distance from the edge. Mean $( \pm 95 \%$ confidence intervals $)$ predicted number of individuals or species at three distances $(0,50$ and $100 \mathrm{~m})$ from the forest edge. 
TABLE 2. Generalised Linear Model results. Degrees of freedom $(\mathrm{df})=1$ for Leaf litter cover and Leaf litter depth, and 2 for Distance. Residual Deviance is the amount of variation not explained by the models. P-values smaller than $0.05\left(\chi^{2}\right.$ distribution) are in bold face. Theta is the aggregation value (for negative binomial error models only) with lower values indicating a higher degree of aggregation. Theta SE is the standard error of Theta. Prediction Holds indicates the species response to distance from the edge coincided with the predicted response according to their classification as forest $(\mathrm{F})$, generalist $(\mathrm{G})$ or open habitat species $(\mathrm{O})$. $\mathrm{Y}=$ yes the species responded as predicted, $\mathrm{N}=$ no it did not respond as predicted, ? $=$ uncertain response.

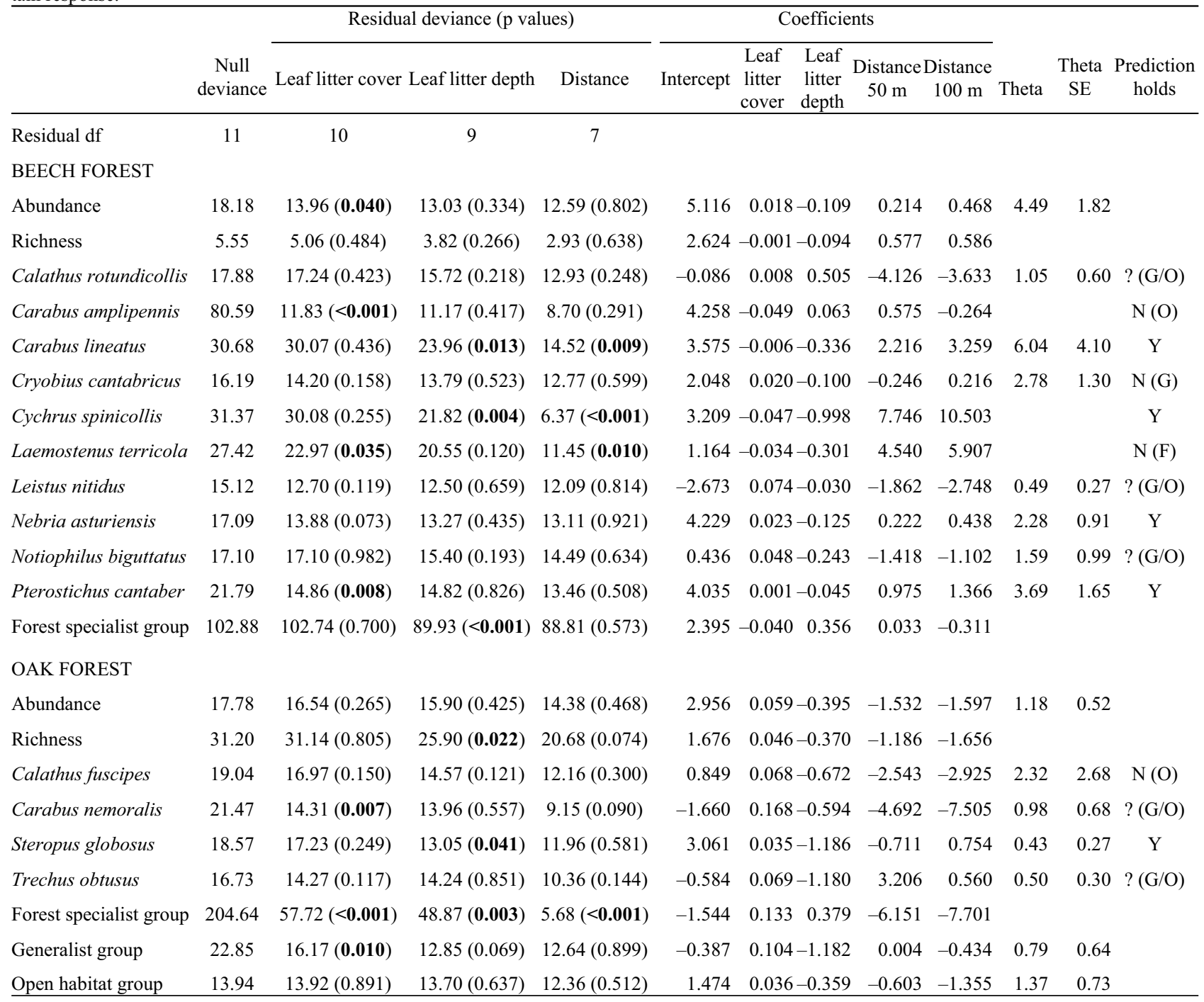

species collected (108 individuals) followed by Calathus rotundicollis (75 individuals).

We found a considerable difference in overall abundance and species richness between forest types. In beech forests we collected 5055 individuals of 22 species and 381 individuals of 29 species in oak forests, i.e. beech forests had a higher total number of individuals and oak forests were species richer. Only eight of the 43 species collected were common to both forest types (Table 1). $58.6 \%$ (17 species) of the species captured in oak forests were open habitat species and $10.3 \%$ (3 species) forest specialists. $13.6 \%$ (3 species) of the species collected in beech forests were open habitat species, and 50\% (11 species) forest specialists.

The results of the hypotheses tested and the estimated coefficients from the Generalised Linear Models are given in Table 2. Theta values indicated aggregated distributions for all species, except Carabus amplipennis,
Cychrus spinicollis and Laemostenus terricola, which were collected from beech forests.

Neither overall abundance nor species richness responded statistically significantly, at the $5 \%$ risk level, to distance from the forest edge in either forest type (Table 2). Generally, however, in beech forests, mean carabid abundance and richness decreased from the forest interior to the edge (Fig. 1a, b). We found the opposite in oak forests where both mean carabid abundance and richness (at the 7\% risk level) were higher at the edge (Fig. $1 \mathrm{a}, \mathrm{b})$. There was a high mean number of species at the edges of oak forests (Fig. 1b), which seemed to be responsible for the higher overall richness of oak compared to beech forests -10 species were collected only at oak forest edges, but their abundances were low (Table 1).

The results of the complementarity calculation indicate that samples along the beech forest gradient were more similar, as they had a higher number of species in 
common than in oak forests (beech forest complementarity values ranged between $0.26-0.35$ and oak forest values between $0.53-0.69$ ).

Three species responded statistically significantly to distance from the edge in beech forests (Carabus lineatus, Cychrus spinicollis and Laemostenus terricola) and none in oak forests (Table 2). The first two species are forest specialists and they responded predictably to the edge as they increased in abundance towards the forest interior (Fig. 1c). According to the literature, Laemostenus terricola is a generalist species, but our results indicated that it is associated with forest interiors (Fig. 1c).

Leaf litter cover and depth in oak and beech forests were higher in the interior (mean value for cover $=62.3 \%$ and $98.2 \%$, and depth $=3.97 \mathrm{~cm}$ and $8.93 \mathrm{~cm}$, respectively) and lower at the edge (mean value for cover = $6.2 \%$ and $37.9 \%$, and depth $=0.25 \mathrm{~cm}$ and $2.14 \mathrm{~cm}$, respectively). In both forest types, we found that half of the species analysed were significantly correlated with one of the leaf litter characteristics (either leaf litter cover or depth). We repeated the analysis for these species without leaf litter cover and depth. Pterostichus cantaber and Carabus amplipennis then responded significantly to distance from the edge (null deviance $=21.53$ and 51.83, residual deviance $=13.46$ and 11.12, $\mathrm{p}=0.018$ and $<0.001$, respectively). Both species are considered to be forest specialists but only Pterostichus cantaber increased in abundance with distance from the edge (Fig. 1d). Nebria asturiensis, a forest specialist, showed a similar distribution pattern to Pterostichus cantaber, but not statistically significantly so (Fig. 1d). The rest of the species did not respond either predictably or statistically significantly to distance from the edge (Table 2, Fig. 1e, f). For example, Cryobius cantabricus, a forest species according to the literature, appeared to be a generalist species, and both Leistus nitidus and Calathus rotundicollis, considered to be forest species, appeared to be either generalist or open habitat species (Table 2).

The beech forest specialists group showed no significant correlation with distance from the edge, but responded positively to leaf litter depth (Table 2). In oak forests we found a significant correlation between the forest specialists group and distance from the edge (Table 2 ), but this group did not respond as predicted - mean number of individuals was higher at the edge (Fig. 1f). The generalist species group responded positively to distance once leaf litter characteristics were removed (null deviance $=102.99$, residual deviance $=79.78, \mathrm{p}=$ $<0.001$ ), but did not show a clear pattern of distribution because of low numbers of individuals (Fig. 1f). The oak forest open habitat species group did not respond statistically significantly to distance from the edge (Table 2).

\section{DISCUSSION}

The main results were: 1) no statistically significant edge effects at the carabid beetle assemblage level in either forest type, 2) three forest species correlated significantly and predictably to distance from the beech forest edge, 3) different carabid beetle responses to the edge were recorded in beech and oak forests (i.e. mean carabid abundance and species richness were higher in beech forest interiors and at oak forest edges), and 4) leaf litter, the only environmental variable measured, appeared to be an important factor affecting the distribution of some species from forest interior to edge.

\section{No edge effects on carabid beetle assemblages}

Our results showed that there was no significant correlation between either abundance or species richness and distance from the edge, i.e. no edge effect at the carabid assemblage level. This result is similar to that found by Kotze \& Samways (2001) at Afromontane forest edges in South Africa. However, several studies in Hungary have shown a significant edge effect on carabid beetles along oak-hornbeam forest-grassland transects (Magura et al., 2001a, b; Molnár et al., 2001; Magura, 2002).

In general, environmental conditions at the edge influence abundance, diversity, species interactions and functional roles of insects (Didham, 1997a), and quite often result in an increase in species richness (Murcia, 1995; Risser, 1995). This increased species richness at the edge was, however, not observed for carabid beetles at oak and beech forest edges in NW Spain. To evaluate the validity of this result, a sampling strategy with more replication is needed, as the small number of sites used in this study may have been partly responsible for not showing an effect, if it exists.

\section{Specific edge effects}

The occurrence of three flightless forest specialist species in beech forests (Carabus lineatus, Cychrus spinicollis and Pterostichus cantaber) correlated significantly with distance from the edge, as predicted, i.e. they were more abundant in the forest interior. Laemostenus terricola, a generalist species collected in beech forests only, was also strongly influenced by the edge, showing a forest specialist distribution pattern. These findings support the results of Spence et al. (1996) and Davies \& Margules (1998) who reported that individual carabid species were susceptible to edge effects and responded differently to the edge according to their habitat requirements.

Unexpectedly, the oak forest specialists group increased significantly in abundance at the forest edge. The reasons for this are unknown, but it is similar to the results of Spence et al. (1996) who showed that some oldgrowth forest specialists occurred in high numbers at forest-clearcut edges.

Although we found several species (open habitat and generalist species) only at the edges of oak forests, these can not be classified as edge associated species (Magura et al., 2001b; Mólnar et al., 2001), because of their low abundance and they may be inhabitants of the adjacent, unsampled grassland (see Heliölä et al., 2001; Magura et al., 2001b).

\section{Differences between beech and oak forests}

We showed that carabid beetle assemblages in Fagus sylvatica and Quercus pyrenaica forests were different (see Thiele, 1977). We found mainly open habitat species in oak forests, and forest specialists in beech forests. 
Beech forests had a higher number of individuals and oak forests were species richer.

Higher carabid species richness in oak forests is associated with a greater small-scale habitat heterogeneity in terms of vegetation structure. This habitat heterogeneity is a factor determining carabid beetle distribution in boreal forests in Finland (Halme \& Niemelä, 1993; Niemelä et al., 1996). The carabid assemblage in beech forest interiors was very similar to that of the edge in terms of species composition and assemblage structure (i.e. abundance distribution), a pattern also found by Heliölä et al. (2001) for carabids at forest-clearcut edges in Finland.

Overall carabid abundance was higher in the interior of both forest types, as recorded by Kotze \& Samways (2001) for Afromontane forests in South Africa, and by Magura et al. (2001a) from oak-hornbeam forests in Hungary. The high abundance in the interiors of beech forest was mainly because of the presence there of two abundant forest specialist species (Nebria asturiensis and Pterostichus cantaber). According to Thiele (1977), more uniform microclimatic conditions in beech forest interiors favours a few very abundant carabid species, which prefer moist and cool conditions. The abundance distribution of the beech forest species was similar to that found by Niemelä (1993) and Koivula (2002) in mature boreal forests in Finland and Niemelä et al. (1993) in Canada; and by Gutiérrez et al. (2004) in beech forests in Spain (but see also Koivula et al., 2002).

We found an unexpected difference between the two types of forests in the response of the carabid assemblages to the edge in beech and oak forests (mean carabid abundance and species richness were higher in the interiors of beech forest and edges of oak forest). This difference was probably associated with greater variability in oak forest structure compared to the more homogeneous beech forests. In the past, oak forests were heavily used by people in NW Spain (Luis-Calabuig et al., 2000) because they were more accessible than the beech forests, which are located in mountains near the Picos de Europa mountain range. Oak forest interiors are more similar to the edges as the canopy is not closed and there are open habitat sites. This allows generalist and open habitat species to disperse across the boundary between the oak interior and the edge.

\section{Carabid beetle response to leaf litter}

The effects of distance from the edge on the distribution patterns of carabids are probably due to the different environmental and biological conditions at different distances from the edge.

We found a great number of statistically significant correlations between leaf litter characteristics (cover and depth) and the species analysed. Leaf litter, therefore, appeared to be one of the factors that influence the distribution of carabid beetles from the interior to the edge of forests (see Koivula et al., 1999). It is worth pointing out that leaf litter was the only environmental variable measured, so its relationship with other variables is unknown. Magura et al. (2001a) and Magura (2002) reported that leaf litter cover significantly affects the distribution of individual species in their habitats, e.g. open habitat species correlate negatively with leaf litter. Molnár et al. (2001) also found that leaf litter cover influenced carabid beetle diversity along forest-grassland transects in Hungary. For epigaeic invertebrates, such as carabid beetles, litter volume provides a "large area for life" (Giller, 1996) for many reasons. For example, more litter may provide more prey or space, or better protection against environmental conditions. Testing the effects of these variables on carabid beetle distribution patterns, will possibly reveal the processes determining their occurrence.

To conclude, the oak and beech forests harboured markedly different carabid beetle assemblages. Smallscale heterogeneity in the oak forests possibly determined the higher number of species there, while the homogeneous beech forest patches were characterised by a lower number of species of which a few were very abundant.

ACKNOWLEDGEMENTS. We thank S. Vehma, S. Lehvävirta, J. Niemelä, R. Tárrega and S. Venn for their constructive comments. B. O'Hara provided statistical advice. Data analyses were carried out using the $\mathrm{R}$ package, URL http://www.R-project.org. We thank the Servicio Territorial de Medio Ambiente de la Junta de Castilla y León who granted permission to work in the forests, and several forest guards who collaborated with us. The study was supported by the Junta de Castilla y León (project 2003/25, reference LE031/03). A. Taboada was financed by the Universidad de León and the Junta de Castilla y León.

\section{REFERENCES}

AbILDSNES J. \& TøMmERÅs B.Å. 2000: Impacts of experimental habitat fragmentation on ground beetles (Coleoptera, Carabidae) in a boreal spruce forest. Ann. Zool. Fenn. 37: 201-212.

AndúJar A. \& Serrano J. 2001: Revisión y filogenia de los Zabrus Clairville, 1806 de la Península Ibérica (Coleoptera, Carabidae). Monografías de la Sociedad Entomológica Aragonesa Vol. 5, Zaragoza, 90 pp.

Angelstam P. 1992: Conservation of communities: The importance of edges, surroundings and landscape mosaic structure. In Hansson L. (ed.): Ecological Principles of Nature Conservation. Elsevier Applied Science, London, pp. 9-70.

Colwell R.K. \& Coddington J.A. 1995: Estimating terrestrial biodiversity through extrapolation. In Hawksworth D.L. (ed.): Biodiversity: Measurement and Estimation. Chapman \& Hall, London, pp. 101-118.

DAVIES K.F. \& MARGULES C.R. 1998: Effects of habitat fragmentation on carabid beetles: experimental evidence. J. Anim. Ecol. 67: 460-471.

De LA Fuente J.M. 1927: Tablas analíticas para la clasificación de los coleópteros de la Península Ibérica. Adephaga: Cicindelidae, Carabidae. J. Bosch, Barcelona, 415 pp.

De VRIES H.H. 1996: Metapopulation structure of Pterostichus lepidus and Olisthopus rotundatus on heathland in the Netherlands: the results from transplant experiments. Ann. Zool. Fenn. 33: 77-84.

Debinski D.M. \& Holt R.D. 2000: A survey and overview of habitat fragmentation experiments. Conserv. Biol. 14: 342-355.

Demaynadier P.G. \& Hunter M.L. JR. 1998: Effects of silvicultural edges on the distribution and abundance of amphibians in Maine. Conserv. Biol. 12: 340-352. 
DidHAM R.K. 1997a: An overview of invertebrate responses to forest fragmentation. In Watt A.D., Stork N.E. \& Hunter M.D. (eds): Forest and Insects. Chapman \& Hall, London, pp. 303-320.

DiDHAM R.K. 1997b: The influence of edge effects and forest fragmentation on leaf litter invertebrates in Central Amazonia. In Laurance W.F. \& Bierregaard R.O. Jr. (eds): Tropical Forest Remnants. Ecology, Management and Conservation of Fragmented Communities. The University Chicago Press, Chicago, London, pp. 55-70.

Donovan T.M., Jones P.W., Annand E.M. \& Thompson F.R. III 1997: Variation in local-scale edge effects: mechanisms and landscape context. Ecology 78: 2064-2075.

GILLER P.S. 1996: The diversity of soil communities, the "poor man's tropical rainforest". Biodivers. Conserv. 5: 135-168.

GutiérRez D., MenÉndez R. \& MÉndez M. 2004: Habitat-based conservation priorities for carabid beetles within the Picos de Europa National Park, northern Spain. Biol. Conserv. 115: 379-393.

HAILA Y. 1999: Islands and fragments. In Hunter M.L. Jr. (ed): Maintaining Biodiversity in Forest Ecosystems. Cambridge University Press, Cambridge, UK, pp. 234-264.

Halme E. \& Niemelä J. 1993: Carabid beetles in fragments of coniferous forest. Ann. Zool. Fenn. 30: 17-30.

Heliölä J., Koivula M. \& Niemelä J. 2001: Distribution of carabid beetles (Coleoptera, Carabidae) across a boreal forestclearcut ecotone. Conserv. Biol. 15 : 370-377.

JeAnNel R. 1941-1942: Coléoptères Carabiques. Faune de France, Vol. $39 \& 40$. Lechevalier, Paris, 1173 pp.

JокIмÄKi J., Huhta E., IтÄмIES J. \& RAнKo P. 1998: Distribution of arthropods in relation to forest patch size, edge, and stand characteristics. Can. J. Forest Res. 28: 1068-1072.

Kapos V., Wandelli E., Camargo J.L. \& Ganade G. 1997: Edge-related changes in environment and plant responses due to forest fragmentation in Central Amazonia. In Laurance W.F. \& Bierregaard R.O. Jr. (eds): Tropical Forest Remnants. Ecology, Management and Conservation of Fragmented Communities. The University Chicago Press, Chicago, London, pp. 33-44.

Koivula M. 2002: Boreal carabid-beetle (Coleoptera, Carabidae) assemblages in thinned uneven-aged and clear-cut spruce stands. Ann. Zool. Fenn. 39: 131-149.

Koivula M., Punttila P., Haila Y. \& Niemelä J. 1999: Leaf litter and the small-scale distribution of carabid beetles (Coleoptera, Carabidae) in the boreal forest. Ecography 22: 424-435.

Koivula M., Kukkonen J. \& Niemelä J. 2002: Boreal carabidbeetle (Coleoptera, Carabidae) assemblages along the clear-cut originated succession gradient. Biodivers. Conserv. 11: $1269-1288$.

Kolasa J. \& ZaLEWSKI M. 1995: Notes on ecotone attributes and functions. Hydrobiologia 303: 1-7.

Kotze D.J. \& Samways M.J. 2001: No general edge effects for invertebrates at Afromontane forest/grassland ecotones. Biodivers. Conserv. 10: 443-466.

LAURANCE W.F. 1997: Hyper-disturbed parks: Edge effects and the ecology of isolated rainforest reserves in Tropical Australia. In Laurance W.F. \& Bierregaard R.O. Jr. (eds): Tropical Forest Remnants. Ecology, Management and Conservation of Fragmented Communities. The University Chicago Press, Chicago, London, pp. 71-83.

Lindroth C.H. 1974: Coleoptera Carabidae. Handbooks for the Identification of British Insects. Vol. 4(2). Royal Entomological Society, London, pp. 1-148.

LuFF M.L. 1996: Use of carabids as environmental indicators in grasslands and cereals. Ann. Zool. Fenn. 33: 185-195.
Luis-Calabuig E., Tárrega R., Calvo L., Marcos E. \& ValBUENA L. 2000: History of landscape changes in Northwest Spain according to land use and management. In Trabaud L. (ed.): Life and Environment in the Mediterranean. Wit Press, Southampton, UK, pp. 43-86.

MaguRA T. 2002: Carabids and forest edge: spatial pattern and edge effect. Forest Ecol. Manag. 157: 23-37.

MaguRA T. \& TÓTHMÉRÉSz B. 1998: Edge effect on carabids in an oak-hornbeam forest at the Aggtelek National Park (Hungary). Acta Phytopath. Entomol. Hung. 33: 379-387.

Magura T., Tóthmérész B. \& MolnÁr T. 2001a: Edge effect on carabid assemblages along forest-grass transects. Web Ecol. 2: 7-13.

Magura T., Tóthmérész B. \& Molnár T. 2001b: Forest edge and diversity: Carabids along forest-grassland transects. Biodivers. Conserv. 10: 287-300.

Matlack G.R. \& Litvaitis J.A. 1999: Forest edges. In Hunter M.L. Jr. (ed.): Maintaining Biodiversity in Forest Ecosystems. Cambridge University Press, Cambridge, United Kingdom, pp. 210-233.

McColLin D. 1998: Forest edges and habitat selection in birds: a functional approach. Ecography 21: 247-260.

Molnár T., Magura T., Tóthmérész B. \& Elek Z. 2001: Ground beetles (Carabidae) and edge effect in oak-hornbeam forest and grassland transects. Eur. J. Soil Biol. 37: 297-300.

MurCiA C. 1995: Edge effects in fragmented forests: implications for conservation. Trends Ecol. Evol. 10: 58-62.

NieMELÄ J. 1993: Mystery of the missing species: speciesabundance distribution of boreal ground-beetles. Ann. Zool. Fenn. 30: 169-172.

Niemelä J. 2001: Carabid beetles (Coleoptera: Carabidae) and habitat fragmentation: a review. Eur. J. Entomol. 98: 127-132.

Niemelä J., Langor D. \& Spence J.R. 1993: Effects of clear-cut harvesting on boreal ground-beetle assemblages (Coleoptera: Carabidae) in Western Canada. Conserv. Biol. 7: 551-561.

Niemelä J., Haila Y. \& Punttila P. 1996: The importance of small-scale heterogeneity in boreal forests: variation in diversity in forest-floor invertebrates across the succession gradient. Ecography 19: 352-368.

Ortuño V.M. \& Marcos J.M. 2003: Los Caraboidea (Insecta: Coleoptera) de la comunidad autónoma del País Vasco. Vol. 1. Servicio Central de Publicaciones del Gobierno Vasco, 573 pp.

PAtON P.W.C. 1994: The effect of edge on avian nest success: How strong is the evidence? Conserv. Biol. 8: 17-26.

Penas A., García M.E. \& Herrero L. 1995: Series de vegetación. Atlas del medio natural de la provincia de León. Instituto Tecnológico Geominero de España y Diputación de León, León, 104 pp.

Quinn G.P. \& KeOugh M.J. 2002: Experimental Design and Data Analysis for Biologists. Cambridge University Press, Cambridge, $537 \mathrm{pp}$.

Rainio J. \& Niemelä J. 2003: Ground beetles (Coleoptera: Carabidae) as bioindicators. Biodivers. Conserv. 12: 487-506.

RisSER P.G. 1995: The status of the science examining ecotones. BioScience 45: 318-325.

Salgado J.M., RodríGUEZ M.E. \& Gallardo J.F. 1998: Effect of soil characteristics on the composition of ground beetle communities in some deciduous oak coppices in western Spain (Coleoptera: Carabidae). G. It. Entomol. 9: 143-153.

Serrano J. 2003: Catálogo de los Carabidae (Coleoptera) de la Península Ibérica. Monografías de la Sociedad Entomológica Aragonesa Vol. 9, Zaragoza, 130 pp. 
Spence J.R., Langor D.W., Niemelä J., Cárcamo H.A. \& Currie C.R. 1996: Northern forestry and carabids: the case for concern about old-growth species. Ann. Zool. Fenn. 33: 173-184.

Stevens S.M. \& Husband T.P. 1998: The influence of edge on small mammals: evidence from Brazilian Atlantic forest fragments. Biol. Conserv. 85: 1-8.

Thiele H.-U. 1977: Carabid Beetles in their Environments. A study on Habitat Selection by Adaptations in Physiology and Behaviour. Springer-Verlag, Berlin, Heidelberg, New York, $369 \mathrm{pp}$.

TisCHENDORF L. 1998: A simulation experiment on the potential of hedgerows as movement corridors for forest carabids. Ecol. Model. 106: 107-118.

Trautner J. \& Geigenmüller K. 1987: Tiger Beetles, Ground Beetles: Illustrated Key to the Cicindelidae and Carabidae of Europe. Margraf, Germany, 488 pp.

Turton S.M. \& Freiburger H.J. 1997: Edge and aspect effects on the microclimate of a small tropical forest remnant on the
Atherton Tableland, Northeastern Australia. In Laurance W.F. \& Bierregaard R.O. Jr. (eds): Tropical Forest Remnants. Ecology, Management and Conservation of Fragmented Communities. The University Chicago Press, Chicago, London, pp. $45-54$.

VÁzqUEZ M.G. 1990: Estudio faunístico, biogeográfico y ecológico de los Caraboidea (Coleoptera) entre las cuencas de los ríos Bernesga, Torío y Porma (León, España). $\mathrm{PhD}$. Thesis, Universidad de León, León, Spain, 455 pp.

White G.C. \& BennetTs R.E. 1996: Analysis of frequency count data using the negative binomial distribution. Ecology 77: 2549-2557.

Winder L., Holland J.M., Perry J.N., Woolley C. \& AlexANDER C.J. 2001: The use of barrier-connected pitfall trapping for sampling predatory beetles and spiders. Entomol. Exp. Appl. 98: 249-258.

Received March 30, 2004; revised June 4, 2004; accepted July 28, 2004 